\title{
Correction to: Sales Assistants in the Making: Learning Through Responsibility
}

\author{
Kaja Reegård ${ }^{1,2}$ \\ Published online: 6 February 2018 \\ (C) The Author(s) 2018. This article is an open access publication
}

\section{Correction to: Vocations and Learning (2015) 8:117-133 https://doi.org/10.1007/s12186-015-9129-0}

The article Sales Assistants in the Making: Learning Through Responsibility, written by Kaja Reegård, was originally published Online First without open access. After publication in volume 8, issue 2, pages 117-133 the author decided to opt for Open Choice and to make the article an open access publication. Therefore, the copyright of the article has been changed to (C) The Author(s) 2018 and the article is forthwith distributed under the terms of the Creative Commons Attribution 4.0 International License (http://creativecommons.org/licenses/by/4.0/), which permits use, duplication, adaptation, distribution and reproduction in any medium or format, as long as you give appropriate credit to the original author(s) and the source, provide a link to the Creative Commons license, and indicate if changes were made.

Open Access This article is distributed under the terms of the Creative Commons Attribution 4.0 International License (http://creativecommons.org/licenses/by/4.0/), which permits unrestricted use, distribution, and reproduction in any medium, provided you give appropriate credit to the original author(s) and the source, provide a link to the Creative Commons license, and indicate if changes were made.

The online version of the original article can be found at https://doi.org/10.1007/s12186-015-9129-0

\section{Kaja Reegård}

kaja.reegard@sos.uib.no

1 Department of Sociology, University of Bergen, P.O. Box 7802, 5020 Bergen, Norway

2 Fafo Institute for Labour and Social Research, Oslo, Norway 